\begin{tabular}{c} 
JURNAL ILMIAH \\
STOK BINA GUNA MEDAN \\
Volume 7 Nomor 2 ; November 2019 \\
\hline
\end{tabular}

\title{
PENINJAUAN MODEL PEMBINAAN GIZI OLAHRAGAWAN
}

\author{
Ratna Dewi $^{1}$, Ahmad Al Munawar ${ }^{2}$, Liliana Puspa Sari ${ }^{3}$ \\ 1,2,3 Sekolah Tinggi Olahraga dan Kesehatan Bina Guna \\ email :wushubinaguna@gmail.com
}

\begin{abstract}
ABSTRAK
Pembentukan gizi merupakan salah satu teknik untuk mencapai prestasi olahragawan di Sumatera Utara (Sumut). Penelitian yang dilakukan adalah melakukan peninjauan terhadap model pembinaan gizi olahragawan pada cabang olahraga yang memiliki prestasi di Pekan Olahraga Nasional (PON). Metode penelitian yang digunakan metode survei kualitatif. Subjek penelitian pada penelitian adalah cabang olahraga Sumatera Utara yang bertanding di Pekan Olahraga Nasional (PON) tahun 2016 Jawa Barat yaitu peraih mendali emas terbanyak diantaranya cabang olahraga Wushu, Karate, dan Pencak Silat. Teknik perolehan data wawancara, dokumentasi, dan forum group discussion (FGD). Uji keabsahan data yaitu dengan credibility, transferability, dependability, dan confirmability. Hasil penelitian diperoleh bahwa model pembinaan gizi olahraga dilakukan dengan pemberian kebutuhan gizi yaitu karbohidrat, protein, lemak, vitamin, mineral, dan air. Peninjauan model pembinaan diterapkan berdasarkan kebutuhan kalori atlet. Kalori atlet diukur dengan berdasarkan kebutuhan atlet dan sumber kalori diberikan dengan bahan makanan yang tepat seperti buha, sayuran, ikan, telur, daging, susu, kacangan, dan minum air yang cukup. Model gizi olahragawan dapat memberikan peran pada penampilan atlet saat pertandingan dan memperoleh prestasi seorang olahragawan.
\end{abstract}

Kata Kunci : Peninjauan, Gizi, Olahragawan

\section{PENDAHULUAN}

Gizi seimbang untuk olahraga atau sering dikenal dengan gizi olahragawan perlu diketahui dan dilaksanakan oleh setiap atlet. Gizi olahragawan merupakan salah satu kunci dalam pendukung prestasi seorang atlet, hal ini dilihat dari bentuk kerja fisik yang dilakukan sehari-hari oleh atlet. Gizi yang tepat tidak hanya penting untuk pertumbuhan, pemeliharaan, dan penggantian jaringan tubuh, tetapi juga untuk menyediakan energi. Daya guna jasmaniah pada seorang atlet tidak banyak dipengaruhi oleh jumlah energi yang dihasilkan oleh otot-otot tubuh, akan tetapi lebih banyak ditentukan oleh kemampuan tubuh menggunakan energi yang dihasilkan oleh otot-otot tubuh tersebut untuk melakukan gerakan-gerakan yang diperlukan. 
Salah satu aspek penting untuk mencapai prestasi yang baik bagi seorang atlet adalah dengan memelihara kesehatan tubuh. Salah satu faktor penentu dalam pencapaian prestasi olahraga adalah terpenuhinya komponen fisik, yang terdiri dari kekuatan, kecepatan, kelincahan dan koordinasi, tenaga, daya tahan otot, daya kerja jantung dan paru-paru, kelenturan, keseimbangan, ketepatan dan kesehatan

berolahraga (M. Sajoto, 1995). Berdasarkan uraian di atas dapat disimpulkan bahwa salah satu faktor untuk memperoleh atlet yang berprestasi adalah dengan memelihara kesehatan tubuh, yaitu dengan memelihara gizi yang seimbang sesuai dengan porsi kebutuhan setiap atlet berdasarkan aktivitas yang dilakukan.

Gizi adalah suatu proses organisme menggunakan makanan yang dikonsumsi secara normal melalui proses digesti, absorpsi, transportasi, penyimpanan, metabolisme dan pengeluaran zat-zat yang tidak digunakan untuk mempertahankan kehidupan, pertumbuhan dan fungsi normal dari organ-organ, serta menghasilkan energi - Berdasarkan hal tersebut dapat dikatakan bahwa gizi merupakan alat bantu dalam memenuhi kebutuhan tubuh untuk melakukan aktivitas, selain itu juga gizi dapat menghasilkan keseimbangan antara energi yang keluar dengan energi yang masuk, sehingga pemenuhan gizi pada tubuh merupakan salah satu peran dalam melakukan keseimbangan antara kebutuhan dan penggunaan atau dengan kata lain gizi seimbang.

Penilaian status gizi adalah upaya menginterprestasikan semua informasi yang diperoleh melalui penilaian antropometri, konsumsi makanan, biokimia, dan klinik (Almatsier, Soetardjo, \& Soekarti, 2011). Dari pernyataan tersebut dapat ditarik kesimpulan bahwa bagi masing-masing individu memiliki tingkat kebutuhan gizi yang berbeda, ini dilihat dari penilaian status gizi yang dimiliki oleh seseorang, sehingga kebutuhan gizi dapat diklasifikasikan menjadi beberapa golongan sesuai dengan keadaan tubuh (antropometri) yang dimiliki seperti ibu hamil, ibu menyusui, anak-anak, bayi, remaja, dewasa, usia lanjut, dan seorang atlet atau olahragawan.

Gizi seimbang untuk atlet atau olahragawan memiliki peran penting dalam mencapai sebuah tujuan atlet meraih prestasi. Dengan memperhatikan proses aktivitas dan pengukuran yang tepat sehingga memperoleh tingkat kebutuhan atlet yang sesuai. Menurut (Almatsier et al., 2011)"Kebutuhan terpenting bagi seorang atlet adalah kecukupan energi yang tergantung pada ukuran badan, komposisi tubuh, usia, gender, dan jenis olahraga yang dilakukan. Selain itu juga intensitas lama melakukan olahraga serta efisiensi pergerakan tubuh juga mempengaruhi berapa banyak energi dibutuhkan seorang atlet". Dari pernyataan tersebut dapat dikatakan bahwa setiap atlet memiliki tingkat kebutuhan gizi yang berbeda, sehingga akan memerlukan proporsi kebutuhan gizi bagi setiap atlet yang akan menunjang terhindarnya kelebihan atau kekurang gizi di dalam tubuh.

Proporsi Kebutuhan Gizi Seimbang untuk atlet atau olahragawan menurut (FAO/WHO/UNU Expert Consultation, 2001) "Kebutuhan energi adalah konsumsi energi berasal dari makanan yang diperlukan untuk menutupi pengeluaran energi seseorang bila ia mempunyai ukuran dan komposisi tubuh dengan tingkat aktivitas yang sesuai dengan kesehatan jangka panjang, dan yang memungkinkan 
pemeliharaan aktivitas fisik yang dibutuhkan secara sosial dan ekonomi." Dari tersebut dapat dinyatakan bahwa setiap orang memiliki tingkat aktivitas yang berbeda, sehingga akan menimbulkan tingkat kebutuhan yang berbeda dalam memenuhi kebutuhannya tersebut. Kebutuhan zat gizi bagi atlet berbeda bila dibandingkan dengan kebutuhan zat gizi bukan atlet, sebab aktivitas dan kegiatan yang dilakukan berbeda, serta terdapat kondisi-kondisi tertentu pada saat atlet harus didukung dengan nutrisi yang tepat. Seorang atlet dapat membutuhkan energi hingga 6000 kalori per hari dan ini berupakan kebutuhan dalam kapasitas besar bagi yang bukan atlet.

Menurut Institute of Occupational Medicine atau IOM (dalam Almatsier et al., 2011) menyatakan bahwa "Kekurangan asupan gizi akan menyebabkan terjadinya defisiensi (kekurangan) gizi, sedangkan kelebihan akan menyebabkan hal-hal sebaliknya. Dalam keadaan ektrim kekurangan atau kelebihan gizi dapat menimbulkan penyakit bahkan kematian". Dari hal tersebut dapat disimpulkan bahwa, gizi memiliki peran dalam memelihara kesehatan tubuh bila dicukupkan sesuai dengan kebutuhan dan keseimbangan, sehingga tubuh akan mudah dalam

melakukan perannya menjalankan aktivitas.

Secara sederhana makanan adalah semua yang dimakan dan diminum oleh seorang olahragawan sehari-harinya. Zat makanan adalah bahan-bahan dasar yang menyusun bahan-bahan makanan. Zat makanan atau zat gizi itu ialah: karbohidrat, protein, lemak, vitamin dan mineral.

Makanan yang dimasukkan oleh olahragawan ke dalam tubuhnya hendaknya tertata dengan baik mengikuti arus kebutuhan-kebutuhan dari aktivitas olahragawan tersebut. Dengan pemahaman lain, apabila makanan tersebut tertata dengan baik, tentu saja akan menunjang pencapaian prestasi olahragawan tersebut, dan sebaliknya apabila makanan olahragawan tidak tertata akan menjadi masalah besar dalam meraih prestasi. Menata makanan seorang olahragawan tentu saja mengacu kepada kepentingan cabang olahraga yang ditekuni olahragawan tersebut.

\section{METODE PENELITIAN}

Metode yang digunakan dalam penelitian ini adalah survei deskriptif. Menurut (Notoatmodjo, 2010) menyatakan bahwa "Pada umumnya survei deskriptif digunakan untuk membuat penilaian

terhadap suatu kondisi dan penyelenggaraan suatu program di masa sekarang, kemudian hasilnya digunakan untuk menyusun perencanaan perbaikan program tersebut". Dari hal tersebut, dapat dinyatakan bahwa metode yang digunakan adalah tepat, yakni sesuai dengan latar belakang penelitian yang dilakukan. Oleh karena itu penelitian ini memiliki metode penelitian sebagai cara memperoleh informasi-informasi mengenai keadaan tertentu, sehingga peneltian yang dilakukan sesuai dengan maksud dan tujuan penelitian.

Teknik perolehan data adalah dengan menggunakan Angket, wawancara, dokumentasi, dan forum group discussion (FGD). Uji keabsahan data yaitu dengan credibility, transferability, dependability, dan confirmability. Berdasarkan hal tersebut, peneliti melakukan pengumpulan dengan menggunakan teknik dan instrumen sebagai berikut : 
1) Catatan lapangan deskriptif : ini merupakan bagian yang paling panjang dan menggambarkan segala upaya peneliti untuk merekam rincian yang terjadi di lapangan (Emzir, 2012:67). Catatan lapangan deskriptif yang dilakuan peneliti adalah dengan mencatat seluruh kejadian yang terjadi dan tersedia.

2) Catatan lapangan reflektif : selain materi deskriptif, catatan lapangan berisi kalimat-kalimat dan paragraf-

paragraf yang merefleksikan pemahaman yang lebih bersifat subjektif dari penelitian (Emzir, 2012). Catatan lapangan reflektif yang dilakuan peneliti adalah dengan mencatat perkembangan yang diperoleh peneliti.

\section{HASIL DAN PEMBAHASAN}

\section{a. Hasil Penelitian}

Pelaksanaan penelitian dilakukan pada cabang olahraga unggulan di Sumatera Utara yang memperoleh mendali emas terbanyak pada Pekan Olahraga Nasional (PON) Tahun 2016. Cabang Olahraga yang diteliti adalah : 1) Wushu, 2) Karate, dan 3) Pencak Silat. Perolehan data dijabarkan sebagai berikut :

1) Wushu : peraih mendali terbanyak dengan jumlah atlet 14 Orang. Status gizi pada diri atlet dilakukan dengan melaksanakan pola konsumsi makanan sebagai berikut :

a. Latihan : beras (500gr), telur (2butir), daging (150gr), sirup (25gr), gula (40gr), sayuran (200gr), dan buha-buhan (200gr).

b. Sebelum pertandingan : masakan sayuran campur (150gr), susu nonfat (200cc), sari buah (150cc), dan kue (50gr).
2) Karate peraih mendali terbanyak dengan jumlah atlet 10 Orang. Status gizi pada diri atlet dilakukan dengan melaksanakan pola konsumsi makanan sebagai berikut :

a. Latihan : Beras (500gr), roti (50gr), gula (40gr), mentega (25gr), telur (2 butir), daging (150gr), susu (25gr), sayuran (200gr), dan buah-buahan (200gr).

b. Sebelum pertandingan : ikan (100gr), masakan sayuran campur (150gr), susu (200cc), sari buah (150cc), dan buah-buahan (200gr).

3) Pencak Silat adalah peraih mendali terbanyak dengan jumlah atlet 15 Orang. Status gizi pada diri atlet dilakukan dengan melaksanakan pola konsumsi makanan sebagai berikut :

a. Latihan : beras (500gr), roti (50gr), biskuit (75gr), selai (25gr), sirup (50cc), gula (40gr), mentega (25gr), daging (150gr), dan buah-buahan (200gr).

b. Sebelum Pertandingan : kentang (150gr), daging (100gr), susu (200cc), dan kue (50gr).

Makanan yang dikonsumsi harus variatif untuk menghindari kejenuhan atau gangguan psikologis atlet saat proses persiapan pertandingan. Kebutuhan status gizi dilakukan untuk membuat atlet terhindar dari masalah yang berkaitan dengan kondisi tubuh seperti mudah lelah, hilang konsentrasi, dan akurasi penggunaan tenaga yang tepat pada setiap gerakan.

\section{Pembahasan}

Kebutuhan jumlah gizi pada setiap individu memiliki porsi yang berbeda, perhitungannya berdasarkan pada usia, 
berat badan, jenis kelamin, aktivitas fisik, kondisi lingkungan (suhu), keadaan tertentu (sakit, ibu hamil atau menyusui) (Daryanto, 2015). Kebutuhan energi dibutuhkan oleh seorang atlet diperlukan untuk : (1) metabolisme basal (Angka Metabolisme Basa (AMB)/Kebutuhan sedang istirahat) (Karmiathi, 2016); (2) aktivitas fisik, dan (3) makanan atau pengaruh dinamika khusus SDA (specifik dynamic actionl) dan pada umumnya kebutuhan energi terbesar diperlukan untuk metabolisme basal (Almatsier, Soetardjo, \& Soekarti, 2011:136).

Berdasarkan pedoman gizi seimbang dijelaskan bahwa tingkat kebutuhan bagi atlet dapat terukur dengan ketentuan yang berlaku, sehingga mempermudah atlet dalam memenuhi zat gizi sesuai aturan yang dianjurkan. Perhitungan kebutuhan gizi dapat dihitung berdasarkan faktor kerja fisik sebagaimana perkalian BMR sebagai berikut :

Tabel 8. Faktor Kerja Fisik (Perkalian Dengan BMR)

\begin{tabular}{|l|c|c|}
\hline \multicolumn{1}{|c|}{$\begin{array}{c}\text { Tingkat } \\
\text { Aktivitas }\end{array}$} & $\begin{array}{c}\text { Laki- } \\
\text { laki }\end{array}$ & Perempuan \\
\hline $\begin{array}{l}\text { Istirahat Di } \\
\text { tempat tidur }\end{array}$ & 1,2 & 1,2 \\
\hline $\begin{array}{l}\text { Kerja Sangat } \\
\text { Ringan }\end{array}$ & 1,4 & 1,4 \\
\hline Kerja Ringan & 1,5 & 1,5 \\
\hline $\begin{array}{l}\text { Kerja Ringan- } \\
\text { Sedang }\end{array}$ & 1,7 & 1,6 \\
\hline Kerja Sedang & 1,8 & 1,7 \\
\hline Kerja Berat & 2,1 & 1,8 \\
\hline $\begin{array}{l}\text { Kerja Berat } \\
\text { Sekali }\end{array}$ & 2,3 & 2,0 \\
\hline
\end{tabular}

Sumber : (Tahron \& Usman, 2014)

Perhitungan jumlah kebutuhan kalori per hari bagi atlet dapat dilakukan dengan perhitungan IMT (Indeks Masa Tubuh) dengan rumus berat badan ( $\mathrm{kg}) /$ Tinggi Badan $^{2}$, BMR (basal metabiloc rate) terdapat pada tabel, SDA (specipic dynamic action) dari 10\% BMR, energi aktivitas fisik pada tabel, dan energi latihan berdasarkan tabel. Kebutuhan akan energi

bagi seseorang tergantung pada metabolisme tubuh dan aktivitas fisik serta makanan yang dikonsumsi kemudian diukur dengan hitungan yang baku.

Sebagai atlet maka perlu dalam memiliki kecukupan zat gizi sebelum pertandingan, hal ini berfungsi dalam mempermudah atlet dalam menjalankan pertandingan. Salah satu yang harus terpenuhi sebelum bertanding adalah persediaan energi. Cadangan energi tersimpan pada otot dan hati sebagai glikogen, jika persediaan energi sedikit maka akan mengakibatkan kelelahan karena kehabisan tenaga.

Cadangan glikogen dalam tubuh dapat diperbesar melalui teknik "carboloading" yaitu memberikan masukan karbohidrat sebanyak mungkin ke dalam tubuh atlet sehingga akan mendorong terbentuknya cadangan glikogen dalam jumlah yang cukup besar. Penyediaan energi dapat dilakukan dengan proses carbo-loading dengan memberikan asupan karbohidrat yang tinggi kepada atlet (Moehji, 2009).

Produksi adenosine triphosphate (ATP) pada kerja otot tergantung pada ketersediaan glikogen otot dan glukosa darah. Jaringan otot merupakan simpanan glikogen yang utama (400g atau $6,7 \mathrm{MJ})$, kemudian hati $(70 \mathrm{~g}$ atau $1,2 \mathrm{MJ})$ dan glukosa darah $(2,5 \mathrm{~g}$ atau $342 \mathrm{~kJ})$. Jumlah ini dapat bervariasi dan tergantung faktor seperti intake atau asupan makanan. Walaupun karbohidrat bukan satu-satunya sumber energi, namun karbohidrat lebih dibutuhkan sebagai sumber energi otot untuk aktifitas fisik yang tinggi (Latief \& Dkk, 2000).

Produksi adenosin triphosphate (ATP) selaam kerja otot yang intensif tergantung dari 
ketersediaan glikogen otot dan glukosa darah. Aktivitas fisik ringan memungkinkan dapat dihasilkan dengan sumber karbohidrat yang rendah. Sebaliknya, untuk aktivitas yang tinggi akan membutuhkan sumber energi yang besar. Jaringan otot merupakan simpanan glikogen yang utama (400 g : 6,7 MJ), kemudian hari (70gr : 1,2 MJ) dan glukosa darah (2,5 g : $342 \mathrm{~kJ})$. Jumlah kapasitas persediaan energi bervariasi antara setiap individu sesuai dengan intake (asupan makanan). Kandungan glikogen otot pada atlet endurance yang terlatih dengan diet campuran mempunyai kandungan glikogen otot $130-230 \mathrm{mmol} / \mathrm{kg}$ berat otot (Daryanto, 2015).

Pada jenis olahraga daya tahan (endurance) dengan intensitas yang tinggi seperti maraton, triathlon, bela diri dan cross country sangat membutuhkan simpanan glikogen yang tinggi. Sebab olahraga endurance (aktivitas >90 menit) dan ultra endurance (aktivitas $>4$ jam) bila memiliki simpanan glikogen yang normal maka kebutuhan energi tidak akan terpenuhi, sehingga menyebabkan penurunan pada penampilan olahraga. Untuk mengatasi tersebut dapat dilakukan dengan "Carbohydrate Loading (carbo-loading)" yang berfungsi untuk meningkatkan simpanan glikogen 200-300\% dalam mengatasi kelelahan dan penampilan atlet dapat ditingkatkan.

\section{KESIMPULAN}

Kebutuhan kalori atlet sebagai upaya penigkatan prestasi atlet Sumatera Utara dilakukan melalui pengukuran Basal Metabolic Rate (BMR) dan sumber kalori diberikan dengan bahan makanan yang ringat atau tidak memberatkan pada aspek pencernaannya yaitu sayuran, buah, ikan/telur (sesekali daging), susu (untuk

pagi/malam), kacang-kacangan, dan minum air yang cukup. Peninjauan model gizi olahragawan dapat memberikan peran yang penting dalam memperoleh prestasi seorang olahragawan.

\section{DAFTAR PUSTAKA}

Almatsier, S., Soetardjo, S., \& Soekarti, M. (2011). Gizi Seimbang dalam Daur
Kehidupan. Jakarta: Kompas

Gramedia.

Daryanto, Z. P. (2015). Optimalisasi asupan gizi dalam olahraga prestasi melalui carbohydrat loading. Jurnal Pendidikan Olahraga, 4(1), 101-112.

Emzir. (2012). Metodologi Penelitian Kualitatif Analisis Data. Jakarta: Rajawali.

FAO/WHO/UNU Expert Consultation. (2001). Human Energy Requirements. London: Food and Nutrition Division WHO.

Karmiathi, N. M. (2016). Penentuan Kebutuhan Kalori Harian pada Penderita Diabetes dengan Fuzzy Logic Metode Mamdani. Jurnal Logic, 16(3).

Latief, D., \& Dkk. (2000). Pedoman Pelatihan Gizi Olahraga untuk Prestasi. Jakarta: Direktorat Gizi Masyarakat Depkessej RI.

M. Sajoto. (1995). Pembinaan Kondisi Fisik dalam Olahraga. Semarang: Dahara Prize.

Moehji, S. (2009). Ilmu Gizi 2 Penanggulangan Gizi Buruk. Jakarta: Papas Sinar Sinanti.

Notoatmodjo, S. (2010). Metodologi Penelitian Kesehatan. Jakarta:

Rineka Cipta.

Tahron, \& Usman, K. (2014). Tingkat Pengetahuan Atlet Tinju Pertina Medan tentang Gizi Seimbang. In

Seminar Evaluasi Pendidikan Nasional. Semarang. Retrieved from https://conf.unnes.ac.id/index.php/sne p/II/paper/viewFile/243/137 